\title{
ON SOME CHARACTERIZATIONS OF THE PARTIAL ORDERINGS FOR BOUNDED OPERATORS
}

\author{
Chunyuan Deng And Shungin Wang
}

\begin{abstract}
In this paper, we investigate some common characterizations and various individual properties of the star ordering, the left star ordering, the right star ordering and the minus partial ordering of bounded operators on a Hilbert space. Some generalizations of results known in the literature and a number of new results for bounded operators are derived.
\end{abstract}

Mathematics subject classification (2010): 15A09, 47A05.

Keywords and phrases: Linear operator, partial ordering, Moore-Penrose inverse, group inverse.

\section{REFERENCES}

[1] J. K. BaKsalary AND S. K. Mitra, Left-star and right-star partial orderings, Linear Algebra Appl. 149 (1991), 73-89.

[2] J. K. BAKS Alary, J. HAUKe, X. LiU, S. LiU, Relationships between partial orders of matrices and their powers, Linear Algebra Appl. 379 (2004), 277-287.

[3] J. K. BAKSAlary, O. M. BAKSAlary, X. LiU, G. TRenKler, Further results on generalized and hypergeneralized projectors, Linear Algebra Appl. 429 (2008), 1038-1050.

[4] O. M. Baksalary, G. P. H. Styan, G. Trenkler, On a matrix decomposition of Hartwig and Spindelböck, Linear Algebra Appl. 430 (2009), 2798-2812.

[5] A. Ben-Israel And T. N. E. Greville, Generalized Inverses: Theory and Applications, WileyInterscience, New York, 1974; 2nd Edition, Springer, New York, 2002.

[6] J. BeniteZ AND N. ThOME, The generalized Schur complement in group inverses and $(k+1)$-potent matrices, Linear Multilinear Algebra 54 (2006), 405-413.

[7] S. L. Campbell, The Drazin inverse of an operator, Recent Applications of Generalized Inverses, 250-260, Res. Notes in Math., 66, Pitman, Boston, Mass.-London, 1982.

[8] N. Castro-González And J. J. Koliha, New additive results for the g-Drazin inverse, Proc. Royal Soc. Edinburgh 134A (2004), 1085-1097.

[9] D. S. CVETKović-ILIĆ, A note on the representation for the Drazin inverse of $2 \times 2$ block matrices, Linear Algebra Appl. 429 (2008), 242-248.

[10] D. S. DJordjević And P. S. Stanimirović, On the generalized Drazin inverse and generalized resolvent, Czechoslovak Math. J. 51(126) (2001), 617-634.

[11] G. Dolinar, J. Marovt, Star partial order on $\mathscr{B}(\mathscr{H})$, Linear Algebra Appl. 434 (2011), 319-326.

[12] R. G. Douglas, On majorization, factorization and range inclusion of operators in Hilbert space, Proc. Am. Math. Soc. 17 (1966), 413-416.

[13] M. P. DRAZIN, Natural structures on semigroups with involution, Bull. Amer. Math. Soc. 84 (1978), $139-141$.

[14] J. GROss, Remarks on the sharp partial order and the ordering of squares of matrices, Linear Algebra Appl. 417 (2006), 87-93.

[15] R. E. Hartwig, M. OMladič, P. ŠEmRl, G. P. H. Styan, On some characterizations of pairwise star orthogonality using rank and dagger additivity and subtractivity, Linear Algebra Appl. 237-238 (1996), 499-507.

[16] R. E. Hartwig, G. P. H. Styan, Partially ordered idempotent matrices, in: T. Pukkila, S. Puntanen (Eds.), Proceedings of the Second International Tampere Conference in Statistics, University of Tampere, Tampere, Finland, 1987, 361-383. 
[17] R. E. Hartwig, G. WANG, AND Y. WeI, Some additive results on Drazin inverse, Linear Algebra Appl. 322 (2001), 207-217.

[18] R. E. HARTwig, How to partially order regular elements, Math. Jpn. 25 (1980), 1-13.

[19] E. C. LANCE, Hilbert $C^{*-m o d u l e s-A}$ Toolkit for operator algebraists, Cambridge University Press, Cambridge, 1995.

[20] X. LIU, The partial ordering of normal matrices and its squares, Chinese Journal of Engineering Mathematics 24 (2007), 741-745.

[21] J. MERIKOSKI AND X. LiU, On the star partial ordering of normal matrices, Journal of Inequalities in Pure and Applied Mathematics, 7 (2006), 1-7, Article 17.

[22] S. K. Mitra, The minus partial order and the shorted matrices, Linear Algebra Appl. 83 (1986), 1-27.

[23] P. ŠEmRL, Automorphisms of $B(\mathscr{H})$ with respect to minus partial order, J. Math. Anal. Appl. 369 (2010), 205-213.

[24] P. ŠEMRL, Maps on matrix spaces, Linear Algebra Appl. 413 (2006), 364-393. 